\title{
Site specialists, diet generalists? Isotopic variation, site fidelity, and foraging by loggerhead turtles in Shark Bay, Western Australia
}

\author{
Jordan A. Thomson ${ }^{1, *}$, Michael R. Heithaus ${ }^{1}$, Derek A. Burkholder ${ }^{1}$, \\ Jeremy J. Vaudo ${ }^{1}$, Aaron J. Wirsing ${ }^{2}$, Lawrence M. Dill ${ }^{3}$ \\ ${ }^{1}$ Florida International University, School of Environment, Arts and Society, Marine Sciences Program, \\ North Miami, Florida 33181, USA \\ ${ }^{2}$ School of Environmental and Forest Sciences, University of Washington, Box 352100, Seattle, Washington 98195, USA \\ ${ }^{3}$ Evolutionary and Behavioural Ecology Research Group, Department of Biological Sciences, Simon Fraser University, \\ Burnaby, British Columbia V5A 1S6, Canada
}

\begin{abstract}
Stable isotope data are useful for inferring foraging and niche variation in marine taxa but can be difficult to interpret, in part because different foraging patterns may result in similar isotopic values. Here, we integrate stable isotope analysis $\left(\delta^{13} \mathrm{C}\right.$ and $\left.\delta^{15} \mathrm{~N}\right)$ with behavioral data to investigate the foraging ecology of loggerhead turtles Caretta caretta on a feeding ground in Shark Bay, Western Australia. Large loggerhead turtles showed little among-individual isotopic variance in skin samples, suggesting similar foraging or habitat use patterns over several months or more. Analysis of loggerhead foraging in video data, and comparison with isotopic variance for sympatric green turtles Chelonia mydas, suggest that low isotopic variance among large loggerheads reflects a similar, highly generalized diet within individuals. Higher isotopic variance among smaller turtles may reflect variation in diet, timing of recruitment to neritic habitat or use of food webs varying along other isotopic gradients. Loggerheads showed strong fidelity to the study site over many years, and individuals recaptured frequently showed remarkable affinity for very small geographic areas, often $<5 \mathrm{~km}^{2}$. Thus, a substantial proportion of the Shark Bay loggerhead population comprises site specialists, with larger adults appearing to be diet generalists. Our results also suggest that among-individual isotopic variation found at some loggerhead nesting locations may reflect the isotopic characteristics of preferred migratory or foraging grounds owing to long-term site fidelity and less likely reflects prey specialization by individuals within specific feeding areas.
\end{abstract}

KEY WORDS: Stable isotopes · Foraging ecology · Animal-borne video $\cdot$ Individual specialization · Marine turtle Resale or republication not permitted without written consent of the publisher

\section{INTRODUCTION}

Most chelonid sea-turtle species (i.e. those with a hard shell) recruit to neritic habitats following an extended post-hatching phase in pelagic or oceanic environments (Bolten 2003, but see Hatase et al. 2006, Hawkes et al. 2006, Casale et al. 2008). The for- aging behavior and movements of chelonids in many coastal regions represent an important knowledge gap, limiting our understanding of turtles' functional roles. Available data suggest that chelonids can play important roles by structuring epifaunal, reef, and seagrass communities through prey selection or by acting as bioturbators (Bjorndal 2003, Bjorndal \& 
Jackson 2003, Lazar et al. 2011). However, behavioral and diet data for marine turtles often suffer from important biases that limit the strength of the ecological inferences that can be made. For example, stomach content and fecal analyses tend to underestimate the importance of easily digested, soft-bodied prey in turtle diets (e.g. Plotkin et al. 1993), while flipper and satellite tagging data are primarily available for reproductive females in breeding areas because they can be easily captured during nesting. Where possible, long-term field studies in feeding areas (e.g. Limpus et al. 1994a,b, Heithaus et al. 2002a, 2005) especially involving the integration of complementary field and analytical techniques that can reduce the effect of biases associated with individual data types (e.g. Zbinden et al. 2008) — are highly valuable to scientists and managers. Furthermore, data from relatively pristine ecosystems are particularly important for generating baselines for comparison with more impacted areas (Heithaus et al. 2005, Hamann et al. 2010).

Loggerhead turtles Caretta caretta are distributed throughout the world's tropical and warm temperate oceans (Bolten \& Witherington 2003). Despite being well studied relative to other chelonids (Bjorndal \& Jackson 2003), key aspects of loggerhead foraging ecology remain enigmatic in many regions. For example, the extent to which individuals return to specific areas for foraging between reproductive migrations is not clear, although mounting evidence suggests a high degree of fidelity to feeding sites in some populations (Limpus et al. 1992, Limpus \& Limpus 2001, Avens et al. 2003, Godley et al. 2003, Heithaus et al. 2005, Broderick et al. 2007, Hawkes et al. 2011). Furthermore, intrapopulation variation in foraging behavior and diet is an important, unresolved issue (Vander Zanden et al. 2010). While it is known, generally, that loggerheads consume diverse invertebrate taxa at the population level (reviews in Dodd 1988, Bjorndal 1997; see also Plotkin et al. 1993, Casale et al. 2008, Lazar et al. 2011), relatively less is known about potential foraging variation within populations related to factors such as size, sex, regional influences, or individual specializations (but see Limpus et al. 2001, Tomas et al. 2001, Hatase et al. 2002, Hawkes et al. 2006, Frick et al. 2009). Such information is necessary to improve our understanding of loggerheads' functional roles and evaluate the efficacy of management strategies (Hamann et al. 2010).

Stable isotope analysis (particularly using $\delta^{13} \mathrm{C}$ and $\delta^{15} \mathrm{~N}$ ) has emerged as a valuable tool for quantifying resource use and examining niche variation at different levels of organization (Post 2002, Bearhop et al.
2004, Layman et al. 2007). The utility of stable isotope analysis stems from the fact that isotope ratios in the tissues of consumers predictably reflect those of their prey (Bearhop et al. 2004). The ratio $\delta^{15} \mathrm{~N}$ in a consumer's tissue can be used to infer trophic position, while $\delta^{13} \mathrm{C}$ reflects the ultimate source of carbon in an animal's diet (i.e. primary producers); the $\delta^{13} \mathrm{C}$ values of primary producers may vary along environmental gradients (e.g. inshore to offshore marine habitats), providing insight into consumer habitatuse patterns (review in Hobson 1999). Furthermore, characteristics of $\delta^{13} \mathrm{C}$ and $\delta^{15} \mathrm{~N}$ distributions in bivariate space may be used to evaluate trophic diversity within or among consumer groups (Layman et al. 2007). As such, stable isotopes can provide insight into resource use patterns across levels of organization and over different time scales, depending on the rate of tissue turnover. However, like traditional methods, stable isotope analysis is not without limitations. Most importantly, it is often not possible to determine specific diets using stable isotopes, and multiple diet compositions or foraging patterns may result in similar isotopic values (Newsome et al. 2007).

Stable isotope ratios in slow-turnover tissues (e.g. skin and muscle) have been used to infer amongindividual foraging variation and the dynamics of generalist populations (Bolnick et al. 2003, Bearhop et al. 2004, but see Matthews \& Mazumder 2004). Within a generalist population, a wide dietary niche width may reflect a gradient of foraging behaviors from individual specialists, which consume different subsets of the overall population's resources, to individual generalists, which consume the same broad diet (Van Valen 1965, Bolnick et al. 2003, Bearhop et al. 2004). High isotopic variance in slow-turnover tissues may indicate persistent among-individual differences in foraging (i.e. individual specialization; Bolnick et al. 2003). However, isotopic variation can reflect both bionomic (i.e. related to prey) and scenopoetic (i.e. related to habitat) influences, making its interpretation difficult (Newsome et al. 2007). Thus, it can be valuable to combine stable isotope analysis with traditional behavioral or diet data to evaluate individual foraging patterns (Newsome et al. 2009).

In loggerhead turtles, analysis of isotopic signatures of scute samples from breeding females in the North Atlantic revealed strong among-individual differences, with temporal stability within individuals, suggestive of long-term foraging specialization (Vander Zanden et al. 2010). However, since breeding populations comprise individuals from potentially 
diverse foraging areas, these differences could be explained by diet specialization while in foraging areas or by variation in the isotopic characteristics of preferred foraging locations (Reich et al. 2009, Vander Zanden et al. 2010). For example, oceanic habitats tend to have lower $\delta^{13} \mathrm{C}$ values than neritic habitats, and differential use of these areas for foraging could explain isotopic variation among females on breeding grounds; in the North Pacific, Hatase et al. (2002) combined stable isotope analysis with satellite telemetry to confirm that smaller females with lower $\delta^{13} \mathrm{C}$ values indeed moved to oceanic habitats, while larger females with higher $\delta^{13} \mathrm{C}$ values used neritic areas.

In the present study, we take a similar integrative approach, combining stable isotope analysis $\left(\delta^{13} \mathrm{C}\right.$ and $\delta^{15} \mathrm{~N}$ ) with long- and short-term behavioral data to gain preliminary insight into the foraging ecology of loggerhead turtles at a relatively pristine feeding location in Shark Bay, Western Australia. Using slowturnover skin samples (i.e. months; see 'Materials and methods: Stable isotope analysis'), we quantify the isotopic niche of loggerhead turtles and examine variation in $\delta^{13} \mathrm{C}$ and $\delta^{15} \mathrm{~N}$ ratios related to sex, body size, season, year, and capture location. We then quantify isotopic dispersion within loggerhead size and sex classes and assess the potential for diet specialization at the individual level. To aid in the interpretation of isotopic variation and further elucidate loggerhead turtle behavior, we analyze foraging behavior using animal-borne video and environmental data recorders (AVED) and examine long-term fidelity to the foraging site using a >10 yr flippertagging data set. These analyses are then brought to bear on recently described isotopic niche variation in loggerhead breeding areas.

\section{MATERIALS AND METHODS}

\section{Study site}

Shark Bay, Western Australia (approx. 254ㄴ $\mathrm{S}$, $113^{\circ} 44^{\prime} \mathrm{E}$ ), is a shallow (mostly $<15 \mathrm{~m}$ ), subtropical bay located approximately $800 \mathrm{~km}$ north of Perth. Our research was focused in the bay's Eastern Gulf near the Monkey Mia Resort (Fig. 1, boxed area). The study area is characterized by shallow $(<4.5 \mathrm{~m})$ seagrass banks separated and surrounded by deeper $(>6.0 \mathrm{~m})$ sand-dominated habitat. In addition, there are expansive sand-seagrass flats, typically $<3 \mathrm{~m}$ deep, alongshore. In the present study we include

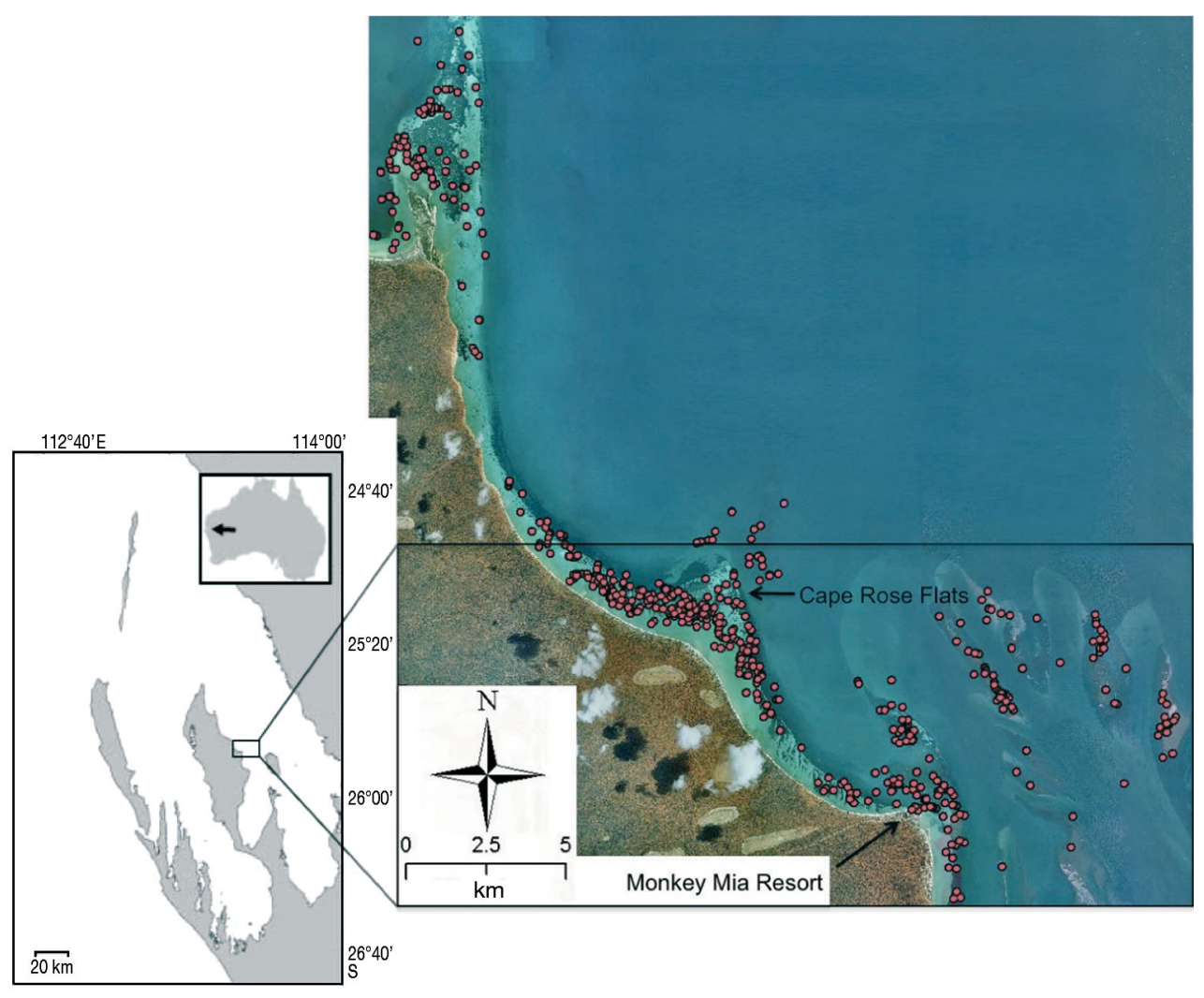

Fig. 1. Caretta caretta. Study area in the Eastern Gulf of Shark Bay, Western Australia, and location of 554 captures (C) of 350 loggerhead turtles between 1999 and 2009. Boxed area comprises the main study area in which most loggerhead captures occurred 
capture data along a stretch of the nearshore sandseagrass habitat extending ca. $15 \mathrm{~km}$ northwest of the main study area, which we visited less frequently but where loggerhead sightings are common (Fig. 1). Sub-adult and adult loggerhead turtles use this region of Shark Bay as a feeding ground year-round (Heithaus et al. 2005).

\section{Stable isotope analysis}

Skin tissue samples were obtained from the trailing edge of the foreflippers of 74 loggerhead turtles captured by hand (Heithaus et al. 2002a) during haphazard searches and systematic transect surveys of the study area between 2005 and 2011. Curved carapace length $(C C L)$ was measured $( \pm 0.5 \mathrm{~cm})$ and turtles were tagged using titanium flipper tags (Department of Environment and Conservation, Western Australia) applied to a proximal foreflipper scute. Turtles were considered to be males if tail length was $\geq 25.0 \mathrm{~cm}$, or 'unclassed', which would include females and immature males, if tail length was $<25.0 \mathrm{~cm}$ (Limpus et al. 1994a,b, Heithaus et al. 2005). Post hoc, unclassed turtles were categorized as likely adult females if CCL was $\geq 95.0 \mathrm{~cm}$, while those with CCL $<95.0 \mathrm{~cm}$ remained unclassed (Heithaus et al. 2005). Captures were allotted to 1 of 2 seasons: cold (June to August) or warm (September to May).

Turnover rates for stable isotopes are not known for adult loggerhead turtles, but the residence times of $\delta^{13} \mathrm{C}$ and $\delta^{15} \mathrm{~N}$ in the skin of juveniles (mean body mass \pm SD at the onset of the trial: $208.8 \pm 97.5 \mathrm{~g}$ ) following an experimental diet shift was ca. $45 \mathrm{~d}$ (Reich et al. 2008), and would be much longer for largerbodied and slower-growing adults (Martínez del Rio et al. 2009). Captive juvenile green turtle Chelonia mydas isotopic signatures equilibrated with diet in $<371$ d (Seminoff et al. 2006a), while turnover in blood plasma, whole blood, and liver tissue of pond slider turtles Trachemys scripta took hundreds of days (Seminoff et al. 2007). The isotopic signatures presented here therefore likely reflect diet over time periods of at least several months.

Samples were placed on ice until the end of the field day, when they were stored at $-20^{\circ} \mathrm{C}$ until processing. Prior to analysis, tissue samples were dried and ground to a fine powder. Between 0.95 and $1.05 \mathrm{mg}$ of ground sample were weighed and analyzed for carbon and nitrogen isotope ratios. Lipid extraction was not performed because C:N ratios (mean \pm SD: $3.06 \pm 0.17$ ) were $<3.5$, suggesting that lipids were a minor component of the tissues (Post et al. 2007). To analyze isotope data, we first used general linear models in the software R v. 2.13.0 to test the effects of size, sex class (male, likely female, or unclassed), season, year, and capture location on $\delta^{13} \mathrm{C}$ and $\delta^{15} \mathrm{~N}$ values. Capture locations were lumped into: (1) a series of offshore seagrass banks divided by deep sand channels, or (2) a strip of sand-seagrass flats running alongshore with adjacent deeper, sandbottom plains. Interactions were not included in this analysis due to low sample sizes in some levels of categorical variables.

We then tested for variation in isotopic dispersion between loggerhead size and sex classes. In some loggerhead populations, $80 \mathrm{~cm}$ CCL is considered an approximate size at maturity (e.g. Casale et al. 2011). However, considerable variation among individuals in size at maturity can occur (Limpus et al. 1994a,b). Thus, we defined the following 3 size classes: (1) $<80.0 \mathrm{~cm} \mathrm{CCL}$, which would include immature and pubescent individuals, (2) 80.0 to $94.5 \mathrm{~cm} \mathrm{CCL}$, which would include a combination of pubescent and adult individuals, and (3) $\geq 95.0 \mathrm{~cm} \mathrm{CCL}$, which would comprise primarily adults (Limpus et al. 1994b). Since sex can only be reliably determined based on morphology (i.e. tail length) for adults, to compare isotopic dispersion between sexes we focused only on the largest size class and compared males with likely females.

We calculated Layman et al.'s (2007) metrics $\left(\delta^{13} \mathrm{C}\right.$ range, $\delta^{15} \mathrm{~N}$ range, total area [TA], mean distance to centroid $[C D]$, mean nearest neighbor distance [NND], and standard deviation of nearest neighbor distance [SDNND]) for each population subgroup. In the present context, increasing $\delta^{15} \mathrm{~N}$ range could reflect greater trophic-level diversity in the diet of a population subgroup or result from variability in the $\delta^{15} \mathrm{~N}$ values of basal resources. Increasing $\delta^{13} \mathrm{C}$ range indicates greater diversity in the ultimate sources of consumed carbon (i.e. primary producers), provided $\delta^{13} \mathrm{C}$ for a particular primary producer does not vary spatially or temporally. TA, calculated as the area of the convex hull encompassing all $\delta^{13} \mathrm{C}-\delta^{15} \mathrm{~N}$ points for a subgroup, provides an estimate of overall trophic diversity. $\mathrm{CD}$ is the average Euclidean distance of each individual's $\delta^{13} \mathrm{C}-\delta^{15} \mathrm{~N}$ point to the centroid for the subgroup, and provides a measure of the average degree of trophic diversity within a subgroup. NND is the mean Euclidean distance to each individual's nearest neighbor and thus reflects the packing of individuals in isotopic space within a subgroup. Finally, SDNND is a measure of variance in NND and reflects the evenness of packing of individuals in isotopic space within a subgroup. 
Some of these metrics are vulnerable to samplesize bias (e.g. TA, NND), which can make comparisons among groups with low and different sample sizes challenging (Jackson et al. 2011). Thus, we also calculated standard ellipses following Jackson et al. (2011), which are the bivariate equivalent of SD for univariate data and provide a measure of isotopic dispersion (i.e. trophic diversity) that is relatively robust to sample-size differences. We then calculated the proportion of each subgroup's standard ellipse overlapped by that of the other subgroups. Finally, to statistically compare the size of standard ellipses, we calculated Bayesian standard ellipses (Jackson et al. 2011) for each subgroup and compared their $95 \%$ credible limits. We ran 100000 Markov-chain Monte Carlo iterations for each subgroup and excluded the first 10000 before calculating posterior sample means and credible limits.

We have not incorporated data on basal resources or potential loggerhead turtle prey here, lacking adequate data on the range of potential prey items consumed by this population. Our goal instead was to conduct a preliminary investigation of isotopic niche variation within this population and provide a foundation for more detailed behavioral and isotopic research. Isotope signatures of basal resources in our study area have been analyzed in a study of the foraging ecology of sympatric green turtles (Burkholder et al. 2011).

\section{Foraging behavior}

AVEDs (National Geographic's CRITTERCAM®; Marshall 1998) were deployed on loggerhead turtles between April and July in 1999, 2000, and 2003 (details in Heithaus et al. 2002b). Briefly, the units included a video recorder and data-logging equipment recording time, depth, and water temperature. To attach AVEDs, a plexiglass plate was affixed to the carapace using cool-setting epoxy (Ten-Set ${ }^{\mathrm{TM}}$ ) and the package was attached to this plate using a small wire and magnesium washer. Units were programmed to stay attached for 3 to $24 \mathrm{~h}$, after which they released via a burnwire mechanism or when the magnesium washer dissolved. A VHF radio transmitter was included in the package to facilitate AVED retrieval.

Feeding was logged when clear evidence of biting and swallowing could be observed via head and neck movements, which were often accompanied by disturbance of the sediment. It was necessary to infer feeding because ingestion could not be directly observed due to camera positioning behind the heads of the turtles. A feeding event ended when neck muscle movements suggested that prey had been swallowed or the turtle moved away from the feeding site. Prey were not usually visible as the turtle approached, but when prey items could be clearly observed, they were identified to the lowest possible taxon.

\section{Foraging-site fidelity}

Between 1999 and 2009, loggerhead turtles were captured by hand (Heithaus et al. 2002a, 2005) during haphazard searches and transect surveys, as described in 'Stable isotope analysis' above. Some captures occurred between 2009 and 2011, but effort during this time period was minimal relative to other years so these data are not analyzed here. Capture data prior to 2004 were first analyzed in Heithaus et al. (2005). Here, capture data from 2004 to 2009 were added to assess foraging-site fidelity over a longer time frame using a larger sample of individuals (350 turtles compared to 223 in the earlier study). Spatiotemporal variation in search effort and capture probability were not controlled for and are undoubtedly influential in this data set. However, this does not interfere with our ability to determine whether a substantial proportion of the population returns to the same feeding site over time. For this data set, captures were divided into seasons corresponding to the timing of breeding migrations: November to March was considered the breeding season and April to October was considered the non-breeding season. If an individual was recaptured within $30 \mathrm{~d}$ of a previous capture, the second encounter was excluded to avoid confounding long-term site fidelity and shortterm residency. For turtles captured in at least 4 seasons, individual histories were plotted in ArcMap v. 9.3. The extension XTools Pro was used to generate convex hulls around each individual's capture locations and calculate their areas as an index of the dispersion of capture locations.

\section{RESULTS}

\section{Stable isotope analysis}

Flipper tissue samples were analyzed for 18 male, 17 likely female, and 39 unclassed loggerhead turtles. Three of these turtles (2 likely females and 1 male) had tissue samples taken on 2 capture occa- 
sions (Fig. 2). One individual was sampled during captures 1 mo apart, another 7 mo apart, and the third 2 yr apart. Samples from the same individual differed from one another by an average $( \pm \mathrm{SD})$ of $0.74 \pm 0.62 \%$ for $\delta^{13} \mathrm{C}$ and $0.90 \pm 0.32 \%$ for $\delta^{15} \mathrm{~N}$ (Fig. 2). Results in the rest of this subsection are based on all data, but analyses were also run on a data set excluding one of each pair of duplicate samples, selected randomly, to test for the effects of pseudoreplication; this exclusion had no substantial impact on our results.

Loggerhead $\delta^{13} \mathrm{C}$ values ranged from -16.43 to $-8.09 \%$ (mean \pm SD: $-13.62 \pm 1.62 \%$, range: $8.34 \%$ ), and $\delta^{15} \mathrm{~N}$ values ranged from 5.66 to $10.40 \%$ (mean \pm SD: $8.02 \pm 1.16 \%$, range: $4.74 \%$; Table 1, Fig. 2 ). The regression models revealed a weak effect of season $\left(F_{1,74}=5.16, \mathrm{p}=0.026\right)$ and a strong effect of CCL $\left(F_{1,74}=29.37, \mathrm{p}<0.001\right)$ on $\delta^{15} \mathrm{~N}$ values; $\delta^{15} \mathrm{~N}$ was higher in the cold season relative to the warm season and decreased with increasing body size. All other $\delta^{13} \mathrm{C}$ and $\delta^{15} \mathrm{~N}$ effects were non-significant. Trends in isotopic dispersion were found between size classes, but not between males and likely females. Based on several metrics, isotopic dispersion was lowest for the largest size class of turtles, highest for the middle size class, and intermediate for the smallest size class (Fig. 2, Table 1). For example, the TA and standard ellipse area (SEA) of the largest size class (11.50 and 3.36 , respectively) were approximately half of their counterpart values for the middle size class $(21.73$ and 7.24, respectively), while sample sizes were similar between the groups. Furthermore, the $\delta^{13} \mathrm{C}$ range of the largest size class $(4.11 \%)$ was approximately half that of the middle size class $(8.15 \%$ ), and just more than half that of the smallest size class $(7.05 \%)$. Isotopic dispersion in the smallest size class was intermediate to the other 2 based on TA, CD, and SEA, although fewer samples were obtained for smaller turtles. NND and SDNND values were the highest for smaller turtles, revealing lower packing and greater unevenness in packing within this subgroup. The $\delta^{15} \mathrm{~N}$ range of the largest size class $(4.70 \%$ ) was slightly greater than that of the other 2 size classes $(4.25 \%$ and $3.47 \%$ for the middle and smallest size class, respectively).

For the smallest size class, $8.5 \%$ of the SEA was overlapped by that of the largest, corresponding to $13.1 \%$ of the largest size class SEA overlap-
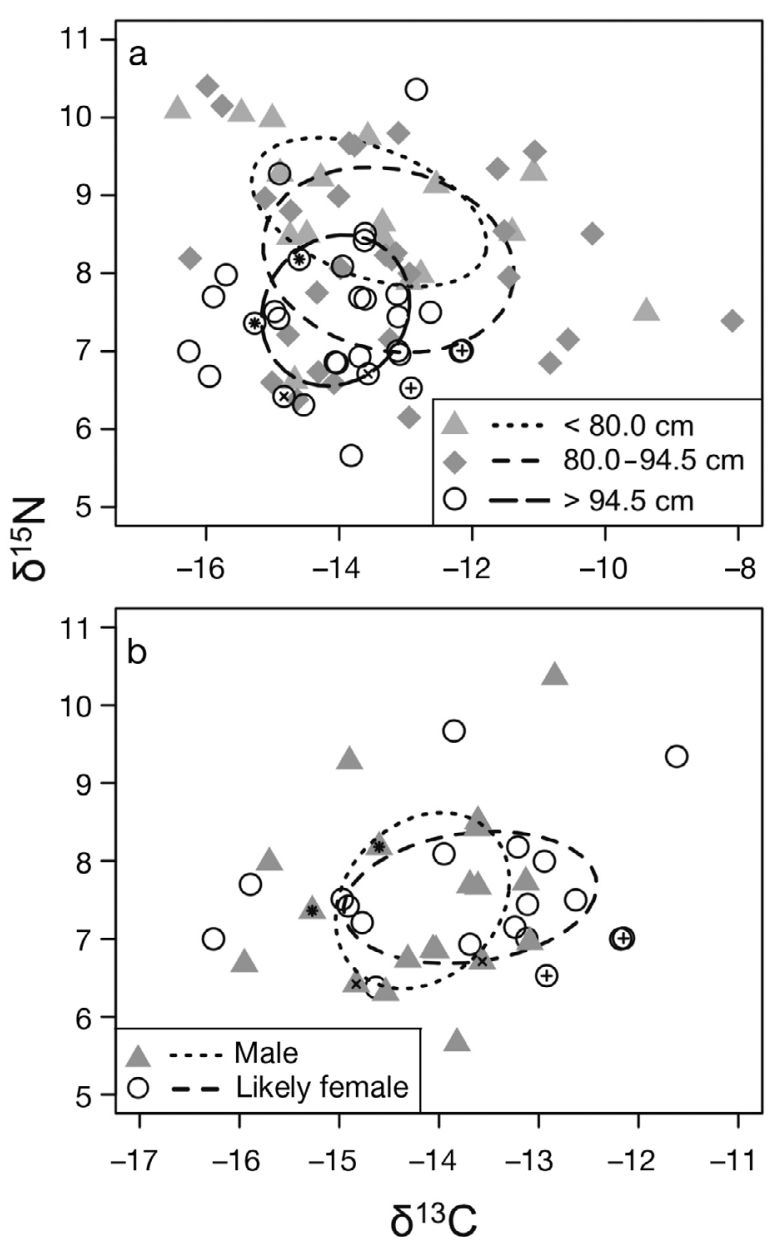

Fig. 2. Caretta caretta. Biplot showing the isotopic signatures of 74 loggerhead turtles by (a) size class and (b) sex class, with standard ellipses for each subgroup. See 'Materials and methods' for class definitions. Symbols containing a same smaller symbol inside represent samples of individuals taken on different capture occasions, i.e. identical small symbol indicates same re-captured individual

Table 1. Caretta caretta. Isotopic dispersion metrics (TA: total area; CD: centroid distance; NND: nearest neighbor distance; SDNND: standard deviation of NND; SEA: standard ellipse area) for $\delta^{13} \mathrm{C}$ and $\delta^{15} \mathrm{~N}$ (ranges in $\%$ ) of size and sex classes. Note that sample sizes include 2 samples from different captures of 3 turtles in the largest size class (2 likely female, 1 male)

\begin{tabular}{|lcccccccc|}
\hline & $\begin{array}{c}\text { Sample } \\
\text { size }\end{array}$ & $\begin{array}{c}\delta^{13} \mathrm{C} \\
\text { range }\end{array}$ & $\begin{array}{c}\delta^{15} \mathrm{~N} \\
\text { range }\end{array}$ & TA & CD & NND & SDNND & SEA \\
\hline Size class (cm) & & & & & & & & \\
$<80$ & 17 & 7.05 & 3.47 & 14.42 & 1.66 & 0.71 & 0.59 & 5.15 \\
$80-94.5$ & 30 & 8.15 & 4.25 & 21.73 & 1.90 & 0.56 & 0.47 & 7.24 \\
$>94.5$ & 30 & 4.11 & 4.70 & 11.50 & 1.28 & 0.35 & 0.41 & 3.36 \\
Sex class & & & & & & & & \\
$\begin{array}{l}\text { Likely female } \\
\text { Male }\end{array}$ & 18 & 3.11 & 4.70 & 9.05 & 1.24 & 0.55 & 0.51 & 3.20 \\
& 17 & 4.64 & 3.29 & 10.15 & 1.33 & 0.53 & 0.50 & 3.52 \\
\hline
\end{tabular}


ping the smallest. For the middle size class, $28.7 \%$ of the SEA was overlapped by that of the largest, corresponding to $61.8 \%$ of the largest size class SEA overlapping the middle size class. Also for the smallest size class, $76.1 \%$ of the SEA was overlapped by that of the middle size class, corresponding to $54.1 \%$ of the middle size class SEA overlapping the smallest (Fig. 2).

The $95 \%$ credible limits of Bayesian ellipse areas displayed high overlap for the smallest (mean: 5.09, lower credible limit [LCL]: 2.62, upper credible limit [UCL]: 7.56) and middle (mean: 7.00, LCL: 4.39, UCL: 9.61) size classes, and the smallest and largest (mean: 3.36, LCL: 2.14, UCL: 4.58) size classes, revealing no significant differences in ellipse size. Overlap in credible limits was marginal between the middle and largest size class (middle LCL: 4.39, largest UCL: $4.58)$, suggesting a trend toward lower isotopic dispersion among large turtles.

The dispersion of male and likely-female isotope values was similar (Fig. 2, Table 1); $64.4 \%$ of male SEA was overlapped by that of likely females, while $70.7 \%$ of likely female SEA was overlapped by that of males. The $95 \%$ credible limits of Bayesian ellipse areas for males (mean: 3.53, LCL: 1.90, UCL: 5.16) and likely females (mean: 3.24, LCL: 1.73, UCL: 4.75) displayed high overlap, revealing no significant difference in ellipse size.

\section{Foraging behavior}

Video data were obtained for 18 loggerhead turtles (mean CCL \pm SD: $94.1 \pm 9.2 \mathrm{~cm}_{i} 1$ turtle lacked a size measurement), with video footage lasting an average $( \pm \mathrm{SD})$ of $2.4 \pm 1.2 \mathrm{~h}$. Video analyses excluded the first $30 \mathrm{~min}$ of footage to allow for post-release stress. Loggerheads demonstrated an opportunistic, mobile foraging tactic, feeding on single items or small patches of prey while traveling along the sea bottom in shallow water (mean depth of dives with feeding \pm SD: $2.48 \pm 1.94 \mathrm{~m})$. Turtles fed predominantly on items on the sea floor, often using the foreflippers to clear debris and locate prey items. Unlike sympatric green turtles that frequently fed on scyphozoan jellyfish or ctenophores in the water column (Burkholder et al. 2011), mid-water foraging was observed only twice for loggerhead turtles. In these cases, feeding occurred out of the field of view and was inferred from head and neck movements so prey could not be identified.

A total of 185 feeding events were recorded for 8 individuals in the AVED deployments. Most of these records (151/185) were by a $102.0 \mathrm{~cm}$ CCL, likely female turtle, which fed intermittently over 75 min while traveling along a sandy bottom in water generally $<2 \mathrm{~m}$ deep. Despite a favorable camera angle and clear, well-lit water, most prey items were not visible on the substrate when the turtle approached a feeding location. In many of these events, the turtle bit into the sand substrate and tugged backward while using its foreflippers to thrust downward, suggesting extraction of infauna (Video S1 available in the supplement at www.int-res.com/articles/suppl/ m453p213_supp/). However, during its foraging trip through the shallows, this turtle also consumed large, mobile gastropods including a northern baler Melo amphora (Video S2 in the supplement) and a sea hare Aplysia sp. (Video S3 in the supplement) that were moving along a sandy bottom. A $76.0 \mathrm{~cm}$ CCL unclassed turtle appeared to consume several large bivalves common to the study area including pearl oysters Pinctada sp. and pen shells Pinna bicolor.

\section{Site fidelity}

The flipper-tagging data set comprised 554 captures of 350 loggerhead turtles between March 1999 and July 2009. Turtle body size, averaged for each individual across all captures, ranged from 63.0 to $111.0 \mathrm{~cm}$ CCL (mean \pm SD: $89.02 \pm 10.7$ cm; Fig. 3). Seventy percent of turtles $(246 / 350)$ were captured only once, while $30 \%(104 / 350)$ were captured multiple times. The mean $( \pm \mathrm{SD})$ number of captures per individual overall was $1.58 \pm 1.15$. For turtles cap-

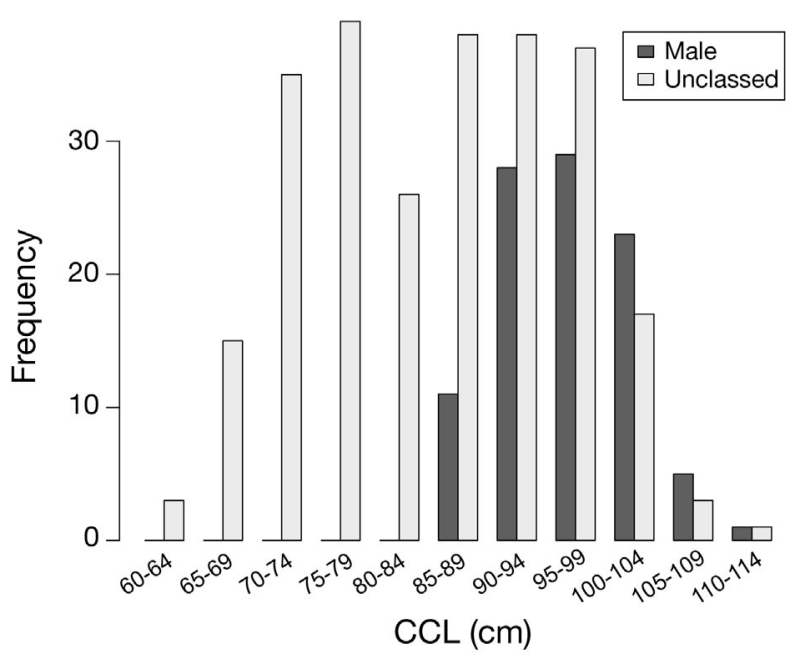

Fig. 3. Caretta caretta. Frequency of body size (curved carapace length [CCL]) of 350 loggerhead turtles captured in the study area between 1999 and 2009 
tured multiple times, the mean $( \pm \mathrm{SD})$ number of captures per individual was $2.96 \pm 1.34$, the maximum number of captures per individual was 8 , and the maximum interval between initial and final captures of an individual was $8.9 \mathrm{yr}$ (Fig. 4). If only turtles initially captured in the first half of the study (1999 to $2004)$ were considered, $37 \%(86 / 233)$ were recaptured overall and $23 \%(53 / 233)$ were recaptured during the second half of the study. One quarter (89/350) of turtles were captured in 2 or more years, and $11 \%$ $(40 / 350)$ were captured in 3 or more years. When broken into year-specific breeding and non-breeding seasons (e.g. 2002 non-breeding, 2002 breeding, 2003 non-breeding), $27 \%(95 / 350)$ of turtles were captured in 2 or more seasons, while $12 \%(44 / 350)$ were captured in 3 or more seasons (Table 2). The mean $( \pm \mathrm{SD})$ area of the convex hulls encompassing
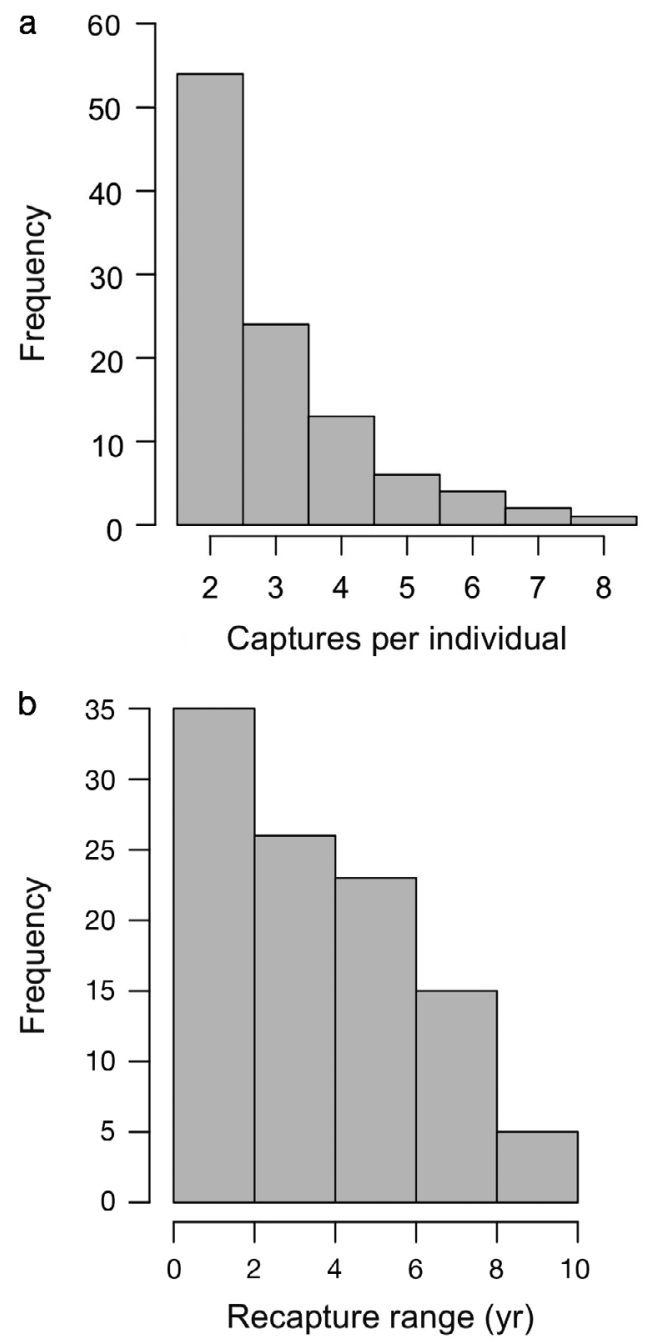

Fig. 4. Caretta caretta. (a) Number of captures per individual and (b) recapture range of loggerhead turtles that were captured multiple times
Table 2. Caretta caretta. Number (n) and percentage of loggerhead turtles captured by the number of years (left) and year-specific breeding/non-breeding seasons (right)

\begin{tabular}{|lrrcrr|}
\hline $\begin{array}{l}\text { No. of years } \\
\text { captured }\end{array}$ & $\mathrm{n}$ & $\%$ & $\begin{array}{c}\text { No. of seasons } \\
\text { captured }\end{array}$ & $\mathrm{n}$ & $\%$ \\
\hline 1 & 261 & 75 & 1 & 255 & 73 \\
2 & 49 & 14 & 2 & 51 & 15 \\
3 & 23 & 7 & 3 & 22 & 6 \\
4 & 12 & 3 & 4 & 13 & 4 \\
5 & 4 & 1 & 5 & 7 & 2 \\
6 & 1 & 0 & 6 & 1 & 0 \\
7 & 0 & 0 & 7 & 0 & 0 \\
8 & 0 & 0 & 8 & 1 & 0 \\
\hline
\end{tabular}

the capture locations of each turtle captured in at least 4 seasons was $4.66 \pm 6.23 \mathrm{~km}^{2}(\mathrm{n}=20) ; 2$ of the 22 individuals captured in 4 or more seasons (Table 2 ) were excluded from this calculation due to missing GPS positions in capture records. The distribution of these areas was positively skewed, with most (15/20) hull areas covering $<5 \mathrm{~km}^{2}$ (Fig. 5). Capture histories of 4 turtles randomly selected from those with capture records in 5 or more seasons are shown in Fig. 6.

\section{DISCUSSION}

\section{Site specialists, diet generalists?}

By integrating stable isotope analysis with animalborne video data and a long-term flipper-tagging database, we were able to gain preliminary insight

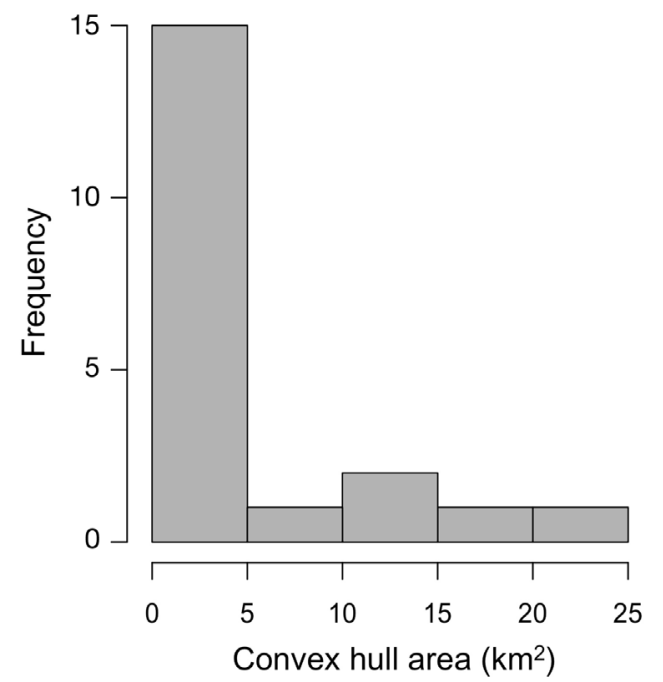

Fig. 5. Caretta caretta. Area of convex hulls encompassing the capture locations of 20 individuals captured in 4 or more seasons 


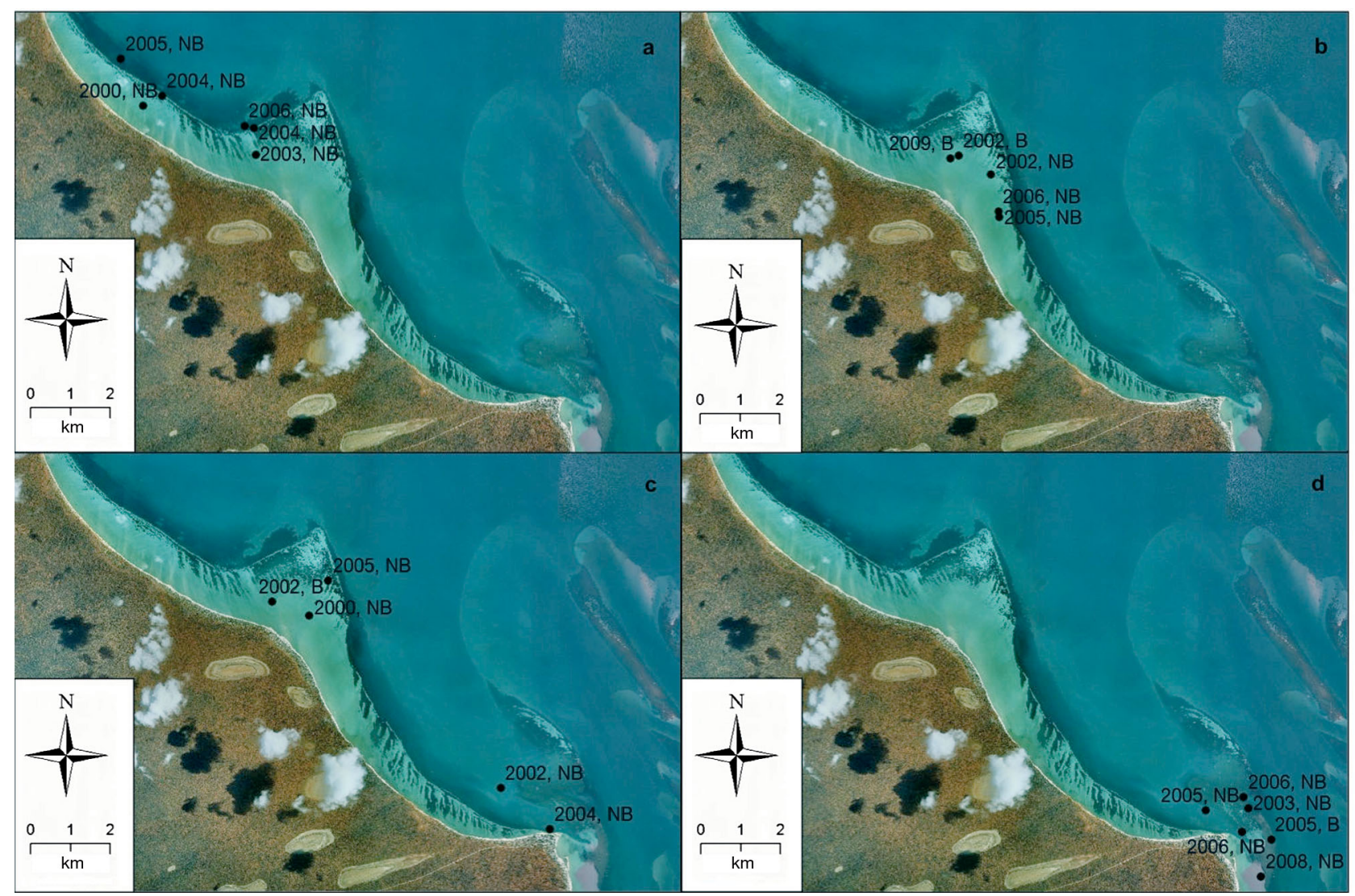

Fig. 6. Caretta caretta. Histories of 4 loggerhead turtles randomly selected from those captured in 5 or more seasons: (a) likely female, $99.8 \mathrm{~cm}$ curved carapace length (CCL); (b) male, $98.1 \mathrm{~cm}$ CCL; (c) male, $102.1 \mathrm{~cm}$ CCL; and (d) male, $93.8 \mathrm{~cm}$ CCL. Labels $(\bullet)$ indicate year of capture followed by season (B: breeding, NB: non-breeding)

into loggerhead-turtle foraging ecology in a relatively pristine sand-seagrass ecosystem. We found evidence of size-, but not sex-related, isotopic niche variation within this population. The largest turtles in our study had similar isotope values - as evidenced by a low $\delta^{13} \mathrm{C}$ range, low isotopic niche area, low average dispersion, a high density, and even distribution of isotope values in this group - suggesting low among-individual trophic diversity. Large turtles did, however, have a slightly larger $\delta^{15} \mathrm{~N}$ range than the other 2 size classes. In contrast, the 2 smaller size classes had more widely distributed isotope values, suggesting greater among-individual trophic diversity. This implies that the foraging behavior of large turtles is similar to one another over the duration of isotopic assimilation in skin samples (several months or more), while that of smaller turtles varies more strongly among individuals. However, differences in foraging behavior that could result in these isotopic distributions comprise a variety of prey- and habitatrelated factors, and complementary data are needed to evaluate these possibilities.
Among large turtles, fidelity to a feeding ground could result in low among-individual isotopic variance. Satellite tracking of 14 large loggerheads in Shark Bay (all $\geq 95.0 \mathrm{~cm} \mathrm{CCL}$, with the exception of 2, which were 91.0 and $91.5 \mathrm{~cm} \mathrm{CCL)} \mathrm{supports} \mathrm{this}$ possibility, revealing strong affinity to the Shark Bay foraging area (Wirsing et al. 2004, E. Olson pers. comm.). These patterns were consistent with flippertagging data, which provide only snapshots of longterm movements. In fact, one turtle showed strong fidelity to the Cape Rose Flats area (Fig. 1) between 2002 and 2009 based on flipper-tag recaptures (Fig. 6b) and was also tracked continuously by satellite telemetry in the same location between February and October 2009, with one possible, but brief, movement of ca. $70 \mathrm{~km}$ outside of the study area. All of the individuals represented in Fig. 6 as showing affinity to nearshore foraging sites were $>93.0 \mathrm{~cm}$ CCL. Thus, fidelity to a foraging site appears to be a likely contributor to the low isotopic variance among large turtles in Shark Bay. Due to capture effort bias in the flipper-tagging data set (e.g. capture of larger turtles 
was often favored for instrument deployments) and lack of satellite data, we cannot yet infer the longterm movements of the smaller turtles.

Low isotopic dispersion may also reflect similarity in the diets of large turtles. This comprises 2 possibilities: (1) large turtles specialize on similar prey to one another, which is a subset of the population's prey base (i.e. narrow niche width at the individual level); or (2) large turtles consume a similar, highly general diet (i.e. broad niche width at the individual level) and, thus, converge on the same isotopic signature. A concurrent study of isotopic variance and foraging in sympatric green turtles in Shark Bay (Burkholder et al. 2011) offers insight into these contrasting explanations. Green turtles in Shark Bay may feed on a small variety of distinct resource groups, primarily seagrasses, benthic macroalgae, and/or gelatinous macroplankton (i.e. scyphozoan jellyfish and ctenophores). Analysis of stable isotopes in green-turtle flipper tissue revealed remarkably wide variation in $\delta^{13} \mathrm{C}(-22.4$ to $-9.8 \%$, range: $12.6 \%$, mean: $-15.0 \%$ ), with no trends in isotopic variation in relation to body size, suggesting long-term individual specialization on particular food types or ratios of food types. Bayesian mixing models (Moore \& Semmens 2008) incorporating data on basal resources and potential prey groups corroborated this inference, as did limited stomach content and AVED data. Thus, for green turtles in Shark Bay, a wide isotopic niche at the population level appears to reflect a spectrum of individual foraging patterns.

In contrast, the $\delta^{13} \mathrm{C}$ range for large loggerheads was quite small $(4.11 \%$ ), but this distribution most likely reflects a wide dietary niche at the individual level for 2 reasons. First, in a single AVED deployment, a large turtle consumed prey ranging from large, mobile gastropods to small infaunal organisms (see Videos S1, S2, \& S3 in the supplement) and it seems unlikely that a specialist individual would consume these diverse prey types, which require different foraging tactics. Importantly, however, our AVED data are limited by sample size and this line of reasoning is currently based on data for a single individual; higher-quality AVED data (e.g. longer-duration deployments, improved image quality, and a better camera angle) are required to make stronger inferences. Second, large body size might be expected to lead to an increasingly general diet, as larger turtles are able to feed on larger prey (Tomas et al. 2001) but may continue to feed on small items, which was observed in the same turtle's AVED deployment. Increased prey diversity in larger turtles has been noted in loggerhead stomach contents (Tomas et al.
2001, Frick et al. 2009, but see Limpus et al. 2001), although this diversity could also reflect bias due to larger stomach (i.e. sample) size. While our data are preliminary, there is some support for the notion that the limited isotopic niche area of large loggerhead turtles reflects a highly general diet at the individual level.

Higher isotopic variance among smaller turtles suggests differences in foraging or movement patterns over several months or more. However, this isotopic distribution is difficult to interpret due to the lack of satellite tracks and diet data for smaller turtles. In marine ecosystems, 4 environmental gradients in $\delta^{13} \mathrm{C}$ are known that could influence isotopic distributions: oceanic to neritic habitats (Hobson et al. 1994), pelagic to benthic zones (France 1995), high to low latitudes (Goericke \& Fry 1994), and food webs with more ${ }^{13} \mathrm{C}$ depleted (e.g. plankton) to more enriched (e.g. seagrasses) basal resources (Newsome et al. 2007, Burkholder et al. 2011). The latitudinal and oceanic-neritic gradients are unlikely to be influential for large loggerhead turtles in Shark Bay considering the similarity of their isotopic signatures and known fidelity to the neritic foraging area. However, we cannot rule out the possibility that smaller turtles exhibit, or have recently exhibited, wider long-term movements resulting in among-individual variation in isotope values. For example, differential timing of recruitment to Shark Bay's neritic habitat from oceanic areas, or movements between these areas for feeding, could lead to greater $\delta^{13} \mathrm{C}$ dispersion among smaller turtles (e.g. McClellan et al. 2010). Indeed, size-related variation in the use of oceanic and neritic foraging areas has been documented elsewhere for this species (Hatase et al. 2002, Hawkes et al. 2006).

Alternatively, variation in $\delta^{13} \mathrm{C}$ values among small turtles could indicate differences in the use of seagrass-, benthic macroalgae-, or phytoplankton-based food webs or individual specializations on particular prey or prey mixtures within Shark Bay (Burkholder et al. 2011, Vaudo \& Heithaus 2011). Size-related variation in $\delta^{15} \mathrm{~N}$ values across all turtle sizes may indicate consumption of prey at different trophic levels or may reflect different resources at the base of the food webs turtles are foraging in (e.g. Burkholder et al. 2011, Vaudo \& Heithaus 2011). Spatiotemporal variation in the $\delta^{13} \mathrm{C}$ and $\delta^{15} \mathrm{~N}$ values of primary producers may also contribute to the isotopic signatures of consumers (Matthews \& Mazumder 2004). In Shark Bay, small but significant seasonal differences have been found in the isotopic signatures of some primary producer groups (gelatinous macroplankton and benthic macroalgae), but not others (seagrass), which may in- 
fluence turtle isotopic distributions (Burkholder et al. 2011). In order to further elucidate mechanisms underlying loggerhead isotopic variance, mixing models (e.g. Moore \& Semmens 2008) incorporating data on primary producers and potential loggerhead prey groups, as well as traditional behavioral and diet data for smaller turtles, are required. Analysis of additional isotopes (e.g. sulfur) or fatty acids in turtle tissues would also help elucidate drivers of isotopic variation across turtle size classes.

\section{Implications for conservation and management}

Our results highlight potentially important issues for management of coastal ecosystems where loggerhead turtles forage. Foremost among these, sizerelated variation in foraging or habitat-use patterns may necessitate integrated management strategies to address threats targeting different population subgroups (Hawkes et al. 2006, McClellan et al. 2010). Survival of late juvenile life stages can have a large per capita impact on population growth rates (Crouse et al. 1987), but in Shark Bay the habits of these individuals are currently unknown. Data on their longterm movements and diets are required to fill this gap and inform management planning.

The extensive use of, and fidelity to, nearshore habitat for foraging may make loggerhead turtles prone to conflict with human activities (e.g. boat traffic, coastal development). In high-use areas, the potential exists for vessel strikes, which are most problematic in shallow water, where turtles are unable to dive to avoid approaching boats (Hazel et al. 2007). In Shark Bay, evidence of boat strikes was minimal; of 350 turtles, 3 had abnormal carapace chips or indentations that may have been caused by collisions, and 1 had 3 parallel grooves in the carapace consistent with healed propeller scars. While boat strikes (at least of the non-lethal variety) appear rare, this does not preclude the possibility of disturbance, because turtles may perceive human stimuli as predators (Frid \& Dill 2002, Wirsing et al. 2008) and respond behaviorally. Responses could include displacement from preferred foraging areas, which should be given attention considering that species showing high site affinity may be limited in their ability to adapt to disturbances or habitat loss (Warkentin \& Hernández 1996).

Strong fidelity to specific foraging sites in chelonid turtles, similar to that exhibited by loggerheads in Shark Bay, has been found in other populations. In the Mediterranean, for example, female green and log- gerhead turtles used similar routes over multiple migrations between nesting beaches, foraging grounds, and overwintering areas (Broderick et al. 2007), and female loggerhead turtles showed fidelity to discrete foraging areas over several months (Godley et al. 2002, 2003). In Queensland, Australia, adult green and loggerhead turtles show fidelity to specific feeding areas between reproductive migrations (Limpus et al. 1992), and loggerheads recaptured after breeding migrations were found within $3.6 \mathrm{~km}$ of their premigration capture location (Limpus \& Limpus 2001). While perhaps not universal (Cheng 2000, Zbinden et al. 2008), it is apparent that affinity to foraging sites can be strong, similar to fidelity of females to natal nesting grounds (Carr \& Ogren 1960).

\section{Implications for isotope studies in loggerhead breeding areas}

Along with foraging insights from preliminary AVED deployments, the isotopic and site-fidelity data bear on among-individual variation in the isotopic signatures of breeding female loggerhead turtles in other populations (Hatase et al. 2002, Reich et al. 2009, Vander Zanden et al. 2010). In a single foraging location in Shark Bay, individual loggerhead turtles particularly larger adults - appear to be site specialists and diet generalists. In other words, these individuals show strong fidelity to a foraging location over time but, while there, consume diverse prey items. This result suggests that isotopic variation among breeding females, which may include individuals from distant and diverse foraging grounds, may likely be influenced by the isotopic characteristics of migratory routes and foraging habitats due to long-term site fidelity and less likely influenced by among-individual prey specialization within foraging areas. To test this hypothesis more thoroughly, however, larger data sets from multiple feeding grounds are needed (Vander Zanden et al. 2010). Supplementary studies on the gastrointestinal contents of turtles, relative to the life histories of the prey items consumed, are also necessary to test the efficacy and limitations of isotopic analyses (Reich et al. 2009).

\section{The value of an integrated approach}

The present study highlights the value of integrating stable isotope analysis with long-term behavioral data in studies of marine-turtle foraging ecology (e.g. Hatase et al. 2002, 2006, Reich et al. 2009, Burk- 
holder et al. 2011). Animal-borne video systems such as CRITTERCAM® appear to have considerable potential for elucidating turtle foraging behavior and diet, relatively non-intrusively, over short sampling periods (e.g. Heithaus et al. 2002a, Seminoff et al. 2006b, Arthur et al. 2007, Burkholder et al. 2011), while stable isotope analysis linked to long-term movement data (e.g. satellite telemetry or flipper tagging) can be used to infer more broad-scale foraging and habitat-use patterns (e.g. Hatase et al. 2002, 2006). Studies combining complementary field and analytical techniques such as these can increase our understanding of turtle foraging ecology, population dynamics, and functional roles, all of which have been identified as important conservation goals (Hamann et al. 2010).

Acknowledgements. We thank the Monkey Mia Dolphin Resort for accommodation and logistic support and the Department of Environment and Conservation (DEC), Western Australia for supplying flipper tags. We appreciate the help of many field assistants and previous Shark Bay Ecosystem Research Project members who contributed to turtle capture and tagging. G. Marshall, B. Buhleier, and M. Bahktiari provided technical support for Crittercam® deployments. P. Heithaus and R. Heithaus provided assistance in the lab. I. Côté and G. Hays provided feedback on an earlier version of this manuscript. This project was supported by Natural Sciences and Engineering Research Council of Canada (NSERC) grant A6869 and PADI grants to L.M.D., US National Science Foundation (NSF) grants OCE0526065 and OCE0745606 to M.R.H., and the College of Arts and Sciences of Florida International University (FIU). J.A.T. was supported by NSERC CGS-M and PGS-D awards and an Animal Behavior Society student research grant. Research was conducted under DEC permits SF002752, NE002120, SF005394, CE001338, and subsequent annual renewals, and under Simon Fraser University (SFU) University Animal Care Committee (UACC) and FIU Institutional Animal Care and Use Committee (IACUC) certification. This is contribution no. 54 from the Shark Bay Ecosystem Research Project.

\section{LITERATURE CITED}

- Arthur KE, O'Neil JM, Limpus CJ, Abernathy K, Marshall GJ (2007) Using animal-borne imaging to assess green turtle (Chelonia mydas) foraging ecology in Moreton Bay, Australia. Mar Technol Soc J 41:9-13

- Avens L, Braun-McNeill J, Epperly S, Lohmann KJ (2003) Site fidelity and homing behavior in juvenile loggerhead sea turtles (Caretta caretta). Mar Biol 143:211-220

Bearhop S, Adams CE, Waldron S, Fuller RA, Macleod H (2004) Determining trophic niche width: a novel approach using stable isotope analysis. J Appl Ecol 73: 1007-1012

Bjorndal KA (1997) Foraging ecology and nutrition of sea turtles. In: Lutz PL, Musick JA (eds) The biology of sea turtles. CRC Press, Boca Raton, FL, p 199-231

Bjorndal KA (2003) Roles of loggerhead turtles in marine ecosystems. In: Bolten AB, Witherington BE (eds) Loggerhead sea turtles. Smithsonian Books, Washington, DC, p 235-254

Bjorndal KA, Jackson JBC (2003) Roles of sea turtles in marine ecosystems: reconstructing the past. In: Lutz PL, Musick JA, Wyneken J (eds) The biology of sea turtles, Vol II. CRC Press, Boca Raton, FL, p 259-273

Bolnick DI, Svanbäck R, Fordyce JA, Yang LH, Davis JM, Hulsey CD, Forister ML (2003) The ecology of individuals: incidence and implications of individual specialization. Am Nat 161:1-28

Bolten AB (2003) Variation in sea turtle life history patterns: neritic vs. oceanic developmental stages. In: Lutz PL, Musick JA, Wyneken J (eds) The biology of sea turtles, Vol II. CRC Press, Boca Raton, FL, p 243-257

Bolten AB, Witherington BE (2003) Loggerhead sea turtles. Smithsonian Books, Washington, DC

Broderick AC, Coyne MS, Fuller WJ, Glen F, Godley BJ (2007) Fidelity and over-wintering of sea turtles. Proc R Soc Lond B 274:1533-1538

Burkholder DB, Heithaus MR, Thomson JA, Fourqurean JW (2011) Diversity in trophic interactions of green sea turtles Chelonia mydas on a relatively pristine coastal foraging ground. Mar Ecol Prog Ser 439:277-293

Carr A, Ogren L (1960) The ecology and migrations of sea turtles, 4: the green turtle in the Caribbean Sea. Bull Am Mus Nat Hist 121:1-48

> Casale P, Abbate G, Freggi D, Conte N, Oliverio M, Argano $\mathrm{R}$ (2008) Foraging ecology of loggerhead sea turtles Caretta caretta in the central Mediterranean Sea: evidence for a relaxed life history model. Mar Ecol Prog Ser 372:265-276

> Casale P, Mazaris AD, Freggi D (2011) Estimation of age at maturity of loggerhead sea turtles Caretta caretta in the Mediterranean using length-frequency data. Endang Species Res 13:123-129

> Cheng IJ (2000) Post-nesting migrations of green turtles (Chelonia mydas) at Wan-An Island, Penghu Archipelago, Tawian. Mar Biol 137:747-754

> Crouse DT, Crowder LB, Caswell H (1987) A stage-based population model for loggerhead sea turtles and implications for conservation. Ecology 68:1412-1423

Dodd CK (1988) Synopsis of the biological data on the loggerhead sea turtle Caretta caretta (Linnaeus 1758). US Fish Wildl Serv Biol Rep 88:1-110

> France RL (1995) Carbon-13 enrichment in benthic compared to planktonic algae: foodweb implications. Mar Ecol Prog Ser 124:307-312

Frick MG, Williams KL, Bolten AB, Bjorndal KA, Martins HR (2009) Foraging ecology of oceanic-stage loggerhead turtles Caretta caretta. Endang Species Res 9:91-97

Frid A, Dill LM (2002) Human-caused disturbance stimuli as a form of predation risk. Conserv Ecol 6:11 www. consecol.org/vol6/iss1/art11

- Godley BJ, Richardson S, Broderick AC, Coyne MS, Glen F, Hays GC (2002) Long-term satellite telemetry of the movements and habitat utilization by green turtles in the Mediterranean. Ecography 25:352-362

Godley BJ, Broderick AC, Glen F, Hays GC (2003) Postnesting movements and submergence patterns of loggerhead marine turtles in the Mediterranean assessed by satellite tracking. J Exp Mar Biol Ecol 287:119-134

Goericke R, Fry B (1994) Variations in marine plankton $\delta^{13} \mathrm{C}$ with latitude, temperature, and dissolved $\mathrm{CO}_{2}$ in the world ocean. Global Biogeochem Cycles 8:85-90 
Hamann M, Godfrey MH, Seminoff JA, Arthur K and others (2010) Global research priorities for sea turtles: informing management and conservation in the 21st century. Endang Species Res 11:245-269

> Hatase H, Takai N, Matsuzawa Y, Sakamoto W and others (2002) Size-related differences in feeding habitat use of adult female loggerhead turtles Caretta caretta around Japan determined by stable isotope analyses and satellite telemetry. Mar Ecol Prog Ser 233:273-281

> Hatase H, Sato K, Yamaguchi M, Takahashi K, Tsukamoto K (2006) Individual variation in feeding habitat use by adult female green sea turtles (Chelonia mydas): Are they obligately neritic herbivores? Oecologia 149:52-64

> Hawkes LA, Broderick AC, Coyne MS, Godfrey MH and others (2006) Phenotypically linked dichotomy in sea turtle foraging requires multiple conservation approaches. Curr Biol 16:990-995

> Hawkes LA, Witt MJ, Broderick AC, Coker JW and others (2011) Home on the range: spatial ecology of loggerhead turtles in Atlantic waters of the USA. Divers Distrib 17: 624-640

> Hazel J, Lawler JR, Marsh H, Robson S (2007) Vessel speed increases collision risk for the green turtle Chelonia mydas. Endang Species Res 3:105-113

> Heithaus MR, Frid A, Dill LM (2002a) Shark-inflicted injury frequencies, escape ability, and habitat use of green and loggerhead turtles. Mar Biol 140:229-236

> Heithaus MR, McLash JJ, Frid A, Dill LM, Marshall GJ (2002b) Novel insights into green sea turtle behavior using animal-borne video cameras. J Mar Biol Assoc UK 82:1049-1050

> Heithaus MR, Frid A, Wirsing AJ, Bejder L, Dill LM (2005) Biology of sea turtles under risk from tiger sharks at a foraging ground. Mar Ecol Prog Ser 288:285-294

Hobson KA (1999) Tracing origins and migration of wildlife using stable isotopes: a review. Oecologia 120:314-326

> Hobson KA, Piatt JF, Pitocchelli J (1994) Using stable isotopes to determine seabird trophic relationships. J Anim Ecol 63:786-798

> Jackson AL, Inger R, Parnell AC, Bearhop S (2011) Comparing isotopic niche widths among and within communities: SIBER - Stable Isotope Bayesian Ellipses in R. J Anim Ecol 80:595-602

Layman CA, Arrington DA, Montaña CG, Post DM (2007) Can stable isotope ratios provide for community-wide measures of trophic structure? Ecology 88:42-48

Lazar B, Gračan R, Katić J, Zavodnik D, Jaklin A, Tvrtković N (2011) Loggerhead sea turtles (Caretta caretta) as bioturbators in neritic habitats: an insight through the analysis of benthic molluscs in the diet. Mar Ecol 32: 65-74

Limpus CJ, Limpus DJ (2001) The loggerhead turtle, Caretta caretta, in Queensland: breeding migrations and fidelity to a warm temperate feeding area. Chelonian Conserv Biol 4:142-153

Limpus CJ, Miller JD, Paramenter CJ, Reimer D, McLachlan N, Webb R (1992) Migration of green (Chelonia mydas) and loggerhead (Caretta caretta) turtles to and from eastern Australian rookeries. Wildl Res 19:347-357

Limpus CJ, Couper PJ, Read MA (1994a) The green turtle, Chelonia mydas, in Queensland: population structure in a warm temperature feeding area. Mem Queensl Mus 35:139-154

Limpus CJ, Couper PJ, Read MA (1994b) The loggerhead turtle, Caretta caretta, in Queensland: population struc- ture in a warm temperature feeding area. Mem Queensl Mus 37:195-204

Limpus CJ, De Villiers DL, De Villiers MA, Limpus DJ, Read MA (2001) The loggerhead turtle, Caretta caretta, in Queensland: feeding ecology in warm temperate waters. Mem Queensl Mus 46:631-645

Marshall GJ (1998) Crittercam: an animal-borne imaging and data logging system. Mar Technol Soc J 32:11-17

- Martínez del Rio C, Wolf N, Carleton SA, Gannes LZ (2009) Isotopic ecology ten years after a call for more laboratory experiments. Biol Rev Camb Philos Soc 84:91-111

Matthews B, Mazumder A (2004) A critical evaluation of intrapopulation variation of $\delta^{13} \mathrm{C}$ and isotopic evidence of individual specialization. Oecologia 140:361-371

> McClellan CM, Braun-McNeill J, Avens L, Wallace BP, Read AJ (2010) Stable isotopes confirm a foraging dichotomy in juvenile loggerhead sea turtles. J Exp Mar Biol Ecol 387:44-51

Moore JW, Semmens BX (2008) Incorporating uncertainty and prior information into stable isotope mixing models. Ecol Lett 11:470-480

Newsome SD, Martínez del Rio C, Bearhop S, Phillips DL (2007) A niche for isotopic ecology. Front Ecol Environ 5: 429-436

Newsome SD, Tinker MT, Monson DH, Oftedal OT and others (2009) Using stable isotopes to investigate individual diet specialization in California sea otters (Enhydra lutris nereis). Ecology 90:961-974

Plotkin PT, Wicksten MK, Amos AF (1993) Feeding ecology of the loggerhead sea turtle Caretta caretta in the northwestern Gulf of Mexico. Mar Biol 115:1-15

Post DM (2002) Using stable isotopes to estimate trophic position: models, methods, and assumptions. Ecology 83: 703-718

Post DM, Layman CA, Arrington DA, Takimoto G, Montaña CG, Quattrochi J (2007) Getting to the fat of the matter: models, methods and assumptions for dealing with lipids in stable isotope analyses. Oecologia 152:179-189

Reich KJ, Bjorndal KA, Martínez del Rio C (2008) Effects of growth and tissue type on the kinetics of ${ }^{13} \mathrm{C}$ and ${ }^{15} \mathrm{~N}$ incorporation in a rapidly growing ectotherm. Oecologia 155:651-663

> Reich KJ, Bjorndal KA, Frick MG, Witherington BE, Johnson C, Bolten AB (2009) Polymodal foraging in adult female loggerheads (Caretta caretta). Mar Biol 157:113-121

- Seminoff JA, Jones TT, Eguchi T, Jones DR, Dutton PH (2006a) Stable isotope discrimination $\left(\delta^{13} \mathrm{C}\right.$ and $\left.\delta^{15} \mathrm{~N}\right)$ between soft tissues of the green sea turtle Chelonia mydas and its diet. Mar Ecol Prog Ser 308:271-278

> Seminoff JA, Jones TT, Marshall GJ (2006b) Underwater behaviour of green turtles monitored with video-timedepth recorders: What's missing from dive profiles? Mar Ecol Prog Ser 322:269-280

Seminoff JA, Bjorndal KA, Bolten AB (2007) Stable carbon and nitrogen isotope discrimination and turnover in pond sliders Trachemys scripta: insights for trophic study of freshwater turtles. Copeia 2007(3):534-542

Tomas J, Aznar FJ, Raga JA (2001) Feeding ecology of the loggerhead turtle Caretta caretta in the western Mediterranean. J Zool (Lond) 255:525-532

> Van Valen L (1965) Morphological variation and width of ecological niche. Am Nat 99:377-390

> Vander Zanden HB, Bjorndal KA, Reich KJ, Bolten AB (2010) Individual specialists in a generalist population: results from a long-term stable isotope series. Biol Lett 6: 
$711-714$

> Vaudo JJ, Heithaus MR (2011) Dietary niche overlap in a nearshore elasmobranch mesopredator community. Mar Ecol Prog Ser 425:247-260

> Warkentin IG, Hernández D (1996) The conservation implications of site fidelity: a case study involving nearcticneotropical migrant songbirds wintering in a Costa Rican mangrove. Biol Conserv 77:143-150

Wirsing AJ, Crane K, Heithaus MR, Charles D, Dill LM (2004) Pilot study of loggerhead turtles in the Shark Bay World Heritage Area: movements and community based

Editorial responsibility: Matthias Seaman, Oldendorf/Luhe, Germany observation. Final report to the Department of the Environment and Heritage, Denham

Wirsing AJ, Abernethy R, Heithaus MR (2008) Speed and maneuverability of adult loggerhead turtles (Caretta caretta) under simulated predatory attack: Do the sexes differ? J Herpetol 42:411-413

Zbinden JA, Aebischer A, Margaritoulis D, Arlettaz R (2008) Important areas at sea for adult loggerhead sea turtles in the Mediterranean Sea: satellite tracking corroborates findings from potentially biased sources. Mar Biol 153: 899-906

Submitted: July 22, 2011; Accepted: January 27, 2012 Proofs received from author(s):April 24, 2012 